\title{
Lingkungan Belajar Berbasis Lesson Study for Learning Community untuk Mahasiswa Calon Guru Matematika
}

\author{
Risnanosanti $^{1 *}$, Mardiah Syofiana ${ }^{2}$, Adi Asmara ${ }^{3}$ \\ 1,2,3Pendidikan Matematika, FKIP, UM Bengkulu, Bengkulu, 38119, Indonesia \\ *risnanosanti@umb.ac.id
}

\begin{abstract}
Abstrak
Komunitas belajar memberikan dampak positif terhadap perkembangan kemampuan pedagogis mahasiswa calon guru matematika. Namun sifat persaingan antar mahasiswa dalam meraih prestasi lebih dominan terjadi di perguruan tinggi. Tujuan dari penelitian ini adalah untuk mengembangkan lingkungan belajar berorientasi komunitas saling belajar dalam lesson study yang valid dan praktis untuk meningkatkan kompetensi pedagogis mahasiswa calon guru matematika. Penelitian ini menggunakan desain penelitian pengembangan model Rowntree. Sedangkan evaluasinya menggunkan model evaluasi formatif Tessmer terdiri dari evaluasi diri (self-evaluation), expert review, uji one to one, small group evaluation dan field test. Tehnik pengumpulan data menggunakan walkthrough, observasi, dokumentasi, angket, wawancara, dan tes. Berdasarkan hasil analisis data menunjukkan bahwa lingkungan belajar berbasis lesson study for learning community yang dikembangkan telah memenuhi kriteria valid dan juga praktis serta mempunyai dampak potensial dalam meningkatkan kemampuan pedagogis mahasiswa calon guru matematika. Berdasarkan analisis data, kompetensi pedagogis sebagian besar mahasiswa sudah baik dengan rincian: 94,16\% mahasiswa mempunyai kompetensi menyusun perencanaan pembelajaran dengan baik. Kompetensi melaksanakan kegiatan pembelajaran dengan baik telah dikuasai oleh $91,66 \%$ mahasiswa. Sedangkan untuk pemahaman mengenai lesson study for learning community telah mencapai 82,5\%. Hasil ini menunjukkan bahwa komunitas saling belajar diantara sesama mahasiswa sebagai suatu lingkungan belajar berbasis lesson study for learning community mampu untuk meningkatkan kompetensi pedagogis mahasiswa calon guru matematika.

Kata kunci: kompetensi pedagogis, lesson study for learning community, lingkungan belajar
\end{abstract}

\begin{abstract}
Learning communities have a positive impact on the development of the pedagogical competence of prospective mathematics teacher students. However, the nature of competition between students is more dominant in universities. This study aims to develop a valid and practical lesson study for learning community-based learning environments to improve the pedagogical competence of student mathematics teacher candidates. This study used the Rowntree model development research design and Tessmer's formative evaluation model, including self-evaluation, expert review, oneto-one evaluation, and small group evaluation. Data collection techniques used walkthrough, observation, documentation, questionnaires, interviews, and tests. The results showed that the learning environment based on the lesson study for the learning community that was developed had met valid and practical criteria and had a potential effect in improving the pedagogical abilities of student mathematics teacher candidates. Based on data analysis, the pedagogical competence of most of the students was good, with details: $94.16 \%$ of students had the competence to prepare a good lesson plan. The competence to carry out learning activities well has been mastered by $91.66 \%$ of students. Meanwhile, the understanding of the lesson study for the learning community has reached $82.5 \%$. These results indicate that the learning
\end{abstract}


community among fellow students as a lesson study for learning a community-based learning environment can improve the pedagogical competence of student mathematics teacher candidates.

Keywords: learning environment, lesson study for learning community, pedagogical competence

Received: November 29, 2020 / Accepted: March 2, 2021 / Published Online: July 13, 2021

\section{Pendahuluan}

Kualifikasi akademik seorang guru memerlukan sejumlah kompetensi yang meliputi kompetensi pedagogis, kepribadian, sosial dan profesional. Kompetensi pedagogis merupakan salah satu kompetensi yang sangat penting untuk dikuasai oleh seorang guru ataupun calon guru (Susanto et al., 2019; Brandt et al., 2019). Hal ini dikarenakan kompetensi pedagogis merupakan kemampuan guru untuk mengelola kegiatan pembelajaran di kelas (Yuliyanti et al., 2019; Sukmawati, 2019). Selain itu kompetensi ini mencakup kemampuan pemahaman dan pengembangan siswa, perencanaan dan pelaksanaan pembelajaran, serta evaluasi pembelajaran (Dirgantoro, 2018).

Namun kenyataan yang dihadapi, secara umum kemampuan pedagogis guru di Indonesia masih berada pada kategori rendah. Berdasarkan hasil uji kompetensi guru rata-rata kemampuan guru secara nasional tidak mencapai pada target yang diharapkan pemerintah. Target yang diharapkan adalah sebesar 55 point, namun hasil uji kompetensi guru rata-rata yang dicapai adalah sebesar 42 di tahun 2014 dan 53 pada tahun 2015 (Rahman et al., 2015; Caraka \& Ika, 2016). Hasil uji kompetensi guru khusus pada kemampuan pedagogis, secara nasional mempunyai rerata 48,94 yang masih di bawah kriteria minimum yaitu sebesar 55. Selain itu, berbagai penelitian yang berhubungan dengan kompetensi pedagogis guru juga menunjukkan hasil yang kurang memuaskan. (Rahman, 2014; Caraka \& Ika, 2016; Syahruddin et al., 2013). Selain itu hasil Uji Kompetensi Guru (UKG) tahun 2018 berdasarkan laman resmi sergur.kemdiknas.go.id menunjukkan rata-rata pencapaian secara nasional sebesar 53,02. Pada tahun 2019 hasil rata-rata UKG secara nasional yang diperoleh sebesar 54,05 berdasarkan informasi dari laman npd.kemdikbud.go.id. Hasil UKG ini menunjukkan bahwa kompetensi guru di Indonesia masih berada di bawah rata-rata standar kompetensi minimal sebesar 55,0. Kompetensi guru yang kurang memuaskan membuat lembaga penghasil tenaga guru seperti LPTK menjadi pihak yang dianggap paling bertanggung jawab.

Materi dalam uji kompetensi guru salah satunya adalah mengenai kompetensi pedagogis. Kompetensi pedagogis tidak dapat dikuasai oleh seseorang dengan tiba-tiba, tetapi 
harus melalui pembelajaran secara sistematis dan berkesinambungan (Asari et al., 2018). Oleh karena itu, diperlukan proses pengembangan untuk meningkatkan kompetensi pedagogis baik untuk mahasiswa yang masih dalam proses pendidikan maupun untuk para guru. Kompetensi pedagogis seseorang dapat ditingkatkan melalui kolaborasi dalam lingkungan atau komunitas yang saling mendukung. Proses pembelajaran secara kolaboratif yang terjadi diantara mahasiswa akan menambah pemahamannya mengenai kompetensi pedagogis.

Pembelajaran kolaboratif mencakup pendekatan pendidikan yang lebih luas dengan melibatkan usaha intelektual diantara sesama mahasiswa, atau antara mahasiswa dengan dosen. Pendekatan pendidikan secara kolaboratif dalam belajar melibatkan sekelompok mahasiswa yang bekerja sama dalam memecahkan masalah. Pengembangan kegiatan pembelajaran secara kolaboratif dapat dilakukan dengan sistem lesson study (Sato, 2014).

Lesson study merupakan suatu sistem pendidikan yang sejak awal dilakukan dalam sistem pendidikan di Jepang. Dalam Lesson study sekelompok guru yang berkumpul secara teratur dalam jangka waktu tertentu untuk bersama-sama merancang, mengimplementasikan, mengevaluasi dan memperbarui proses pembelajaran. Selain itu lesson study juga menunjukkan hasil yang baik dalam meningkatkan kualitas proses belajar mengajar (Wessels, 2018; Kanellopoulou \& Darra, 2019; Risnanosanti et al., 2019ss). Lesson study menekankan pada pentingnya mengamati siswa, namun sebagian besar penelitian yang dilakukan cenderung membahas aktivitas dan pengembangan profesionalisme guru. Oleh karena itu perlu mengkaji lesson study dari perspektif yang berbeda dengan berorientasi pada pemahaman kebutuhan, pengalaman, dan praktik siswa. Sehingga diusulkan Lesson Study for Learning Community (LSLC) sebagai pendekatan yang berbeda dengan fokus pada isu-isu yang berkaitan dengan reformasi sekolah atau dialog yang terjadi antar subjek (Saito \& Atencio, 2015).

Pada awal pengembangannya kegiatan pembelajaran berbasis lesson study mempunyai tiga tahapan kegiatan yaitu plan-do-see. Namu saat ini kegiatan pembelajaran berbasis lesson study mempunyai empat langkah utama yang berbentuk siklus yaitu plan-do-see-redesign (Sato, 2014). Tahapan plan merupakan tahapan awal yang bertujuan untuk mengembangkan perangkat pembelajaran. Tahapan kedua adalah do (pelaksanaan di kelas), tujuannya adalah untuk menerapkan perencanaan pembelajaran yang telah dirancang sebelumnya. Tahapan ketiga merupakan refleksi atau dikenal dengan sebutan see, bertujuan untuk melihat kekuatan dan kelemahan dari pelaksanaan pembelajaran yang dilakukan. Berdasarkan hasil refleksi dilakukan perancangan ulang (redesign). Tahapan redesign dilaksanakan bertujuan untuk 
memperbaiki berbagai kekurangan yang terdapat pada desain pembelajaran sebelumnya (Sato, 2014).

Pengembangan kompetensi guru telah banyak dilakukan oleh para ahli melalui berbagai penelitian, diantaranya adalah kompetensi guru dalam menggunakan tehnologi yang menunjukkan adanya keterkaitan tiga komponen dalam kompetensi guru (Salas-Rueda, 2019; Hernawati \& Jailani, 2019; Ozudogru \& Ozudogru, 2019; Landry, 2010; Guerrero, 2010s). Sedangkan penelitian yang berkaitan dengan lesson study juga telah dilakukan diantaranya adalah penelitian yang melihat peningkatan kompetensi pedagogis guru melalui lesson study, hasil yang diperoleh adalah ada peningkatan kompetensi guru (Asari et al., 2018). Selain itu adanya studi yang melihat pengaruh dari pembelajaran berbasis lesson study terhadap kemampuan berpikir kritis siswa (Risnanosanti et al., 2019). Namun penelitian yang menggunakan LSLC untuk mengembangkan kompetensi pedagogis mahasiswa calon guru khususnya di Kota Bengkulu belum pernah dilakukan sebelumnya. Observasi awal yang dilakukan menunjukkan bahwa mahasiswa belum memahami LSLC dengan baik. Oleh karena itu penelitian ini dilakukan untuk mengembangkan kompetensi pedagogis mahasiswa melalui lingkungan pembelajaran yang berbasis LSLC.

Berdasarkan uraian di atas, tujuan dari penelitian ini yaitu: pertama, untuk mengetahui karakteristik lingkungan belajar yang valid dan praktis melalui LSLC dalam mengembangkan kompetensi pedagogis mahasiswa; dan kedua, untuk mengetahui sejauhmana keefektifan lingkungan belajar melalui LSLC terhadap peningkatan kemampuan pedagogis mahasiswa.

\section{Metode}

Penelitian ini merupakan penelitian pengembangan dengan model Rowntree dengan tiga tahapan. Pemilihan model Rowntree didasarkan pada asumsi bahwa penelitian ini menghasilkan suatu produk berupa lingkungan belajar yang sesuai untuk mengembangkan kompetensi pedagogis mahasiswa. Tahap pertama pada model Rowntree adalah melakukan proses analisis terhadap kebutuhan mahasiswa dan perumusan tujuan pembelajaran yang akan dicapai. Tahap yang kedua adalah mengembangkan topik, menyusun draf awal, membuat prototipe yang akan digunakan dalam proses pembelajaran. Sedangkan tahap yang ketiga adalah mengevaluasi, melalui model evaluasi formatif Tessmer. Proses evaluasi terdiri dari beberapa langkah yaitu: (1) evaluasi diri (self-evaluation); (2) validasi ahli (expert review); (3) validasi siswa (one-to-one evaluation); (4) small group evaluation; dan (5) field test. 
Subjek dalam penelitian ini adalah 34 mahasiswa terdiri dari 8 orang laki-laki dan 26 orang perempuan, yang sedang menempuh mata kuliah micro teaching, di Program Studi Pendidikan Matematika FKIP Universitas Muhammadiyah Bengkulu. Mahasiswa yang terlibat dalam kegiatan penelitian ini merupakan mahasiswa yang telah menempuh mata kuliah model-model pembelajaran, evaluasi proses pembelajaran matematika, strategi pembelajaran matematika dan perencanaan pembelajaran matematika. Pengumpulan data dilakukan melalui walkthrough, observasi, wawancara, kuesioner, dan tes tertulis.

Pengumpulan data dengan cara walkthrough merupakan proses untuk validasi data. Data walkthrough berbentuk komentar yang dikumpulkan dari expert review sebanyak 2 orang ahli dalam bidang pembelajaran matematika dan berpengalaman menerapkan lesson study, rekan dosen sebanyak 3 orang yang tergabung dalam tim pengajar mata kuliah micro teaching. Sedangkan proses uji one-to-one dilakukan terhadap mahasiswa, tahap uji kelompok terbatas (small group) dan tahap uji lapangan. Observasi dan wawancara dilakukan untuk menggali data mengenai implementasi lingkungan belajar berbasis LSLC. Observasi dilakukan sebanyak 2 kali setiap siklusnya sehingga secara keseluruhan terdapat 8 kali observasi pembelajaran yang terjadi. Wawancara dilakukan terhadap dosen pengasuh dan juga mahasiswa subjek penelitian. Ada tiga jenis angket yang digunakan yaitu angket awal (yang diberikan pada kegiatan awal sebanyak 18 item), angket persepsi (15 item), dan angket kepuasan (15 item). Angket dikembangkan oleh tim peneliti dan sebelum digunakan dilakukan validasi terlebih dahulu, dengan nilai $Q_{\text {hit }}$ sebesar 4,67. Sedangkan untuk tes dikembangkan oleh tim peneliti dengan berpandu pada konsep LSLC dan indikator kompetensi pedagogis. Sebanyak 20 butir test pilihan ganda yang sudah diuji validitasnya, dengan nilai Qhit sebesar 4,35. Kemudian butir tes diberikan pada subjek penelitian untuk memperoleh data pemahaman terhadap LSLC dan kompetensi pedagogis mahasiswa. Indikator aspek kompetensi pedagogis yang digunakan dalam penelitian ini diadopsi dan adaptasi dari (Perni, 2019) adalah (1) Menguasai karakteristik siswa, (2) Menguasai teori belajar dan prinsip-prinsip pembelajaran berbasis LSLC, (3) Melaksanakan kegiatan pembelajaran, (4) Memfasilitasi pengembangan potensi siswa, (5) Melaksanakan evaluasi proses dan hasil belajar, dan (6) Melakukan refleksi. Kriteria penilaian angket diadaptasi dari Widoyoko (Widoyoko, 2013)

Tabel 1. Kriteria Penilaian Angket

\begin{tabular}{cc}
\hline Interval Skor & Kriteria \\
\hline $2,7 \leq \mathrm{X} \leq 4$ & Sesuai \\
$1,4 \leq \mathrm{X}<2,7$ & Cukup Sesuai \\
$0 \leq \mathrm{X}<1,4$ & Kurang Sesuai \\
\hline
\end{tabular}


Selanjutnya data dianalisis secara kualitatif. Selain itu data angket kepuasan dan tes tertulis digunakan untuk melihat dampak potensial kegiatan pembelajaran berbasis LSLC terhadap peningkatan kompetensi pedagogis mahasiswa.

\section{Hasil}

Penelitian dimulai dengan melakukan kegiatan pendahuluan untuk memperoleh gambaran pengetahuan mahasiswa mengenai LSLC. Pada tahap ini dilakukan tinjauan pustaka dan uji coba pembelajaran berbasis LSLC untuk mata kuliah micro teaching. Kemudian mahasiswa diberikan angket awal dan wawancara untuk mengetahui pendapat dan persepsinya terhadap pembelajaran yang berbasis LSLC. Penelitian pendahuluan dilakukan pada 12 orang mahasiswa. Hasil penelitian awal diperoleh informasi bahwa hanya 11,7\% mahasiswa yang sudah mengenal LSLC.

Berdasarkan hasil penelitian pendahuluan dan kajian pustaka dirancang desain dan draft awal (draft 1) bahan ajar dan lingkungan belajar berbasis LSLC. Proses perancangan bahan ajar yang dilakukan mengikuti tahapan dalam lesson study. Bahan ajar dirancang secara bersama-sama oleh tim dosen yang mengajar mata kuliah micro teaching. Pada tahap perancangan awal tim dosen berdiskusi mengenai bahan ajar, konteks masalah serta media pembelajaran yang sesuai dengan karakteristik siswa. Topik yang dipilih untuk simulasi di lingkungan kampus adalah materi sistem persamaan linier. Dari hasil diskusi diperoleh draft 1 bahan ajar yang terdiri dari rencana pelaksanaan pembelajaran (RPP), lembar kerja dan diskusi siswa (LKPD), petunjuk untuk guru, dan instrumen tes kemampuan berpikir tingkat tinggi.

Setelah draft 1 selesai dirancang, selanjutnya dilakukan validasi bahan ajar kepada 2 (dua) orang expert review dan rekan sesama dosen. Selain divalidasi oleh para expert review, draft 1 bahan ajar dilanjutkan dengan uji one-to-one. Proses uji one-to-one dilakukan pada 5 (lima) orang mahasiswa yang bukan subjek penelitian. Hasil uji one-to-one adalah data mengenai respon dan komentar mahasiswa berkaitan dengan validasi rencana pembelajaran dan instrumen tes. Kelima orang mahasiswa juga diminta untuk memberikan pendapat mengenai kesulitan yang ditemui dalam memahami bahan ajar. Berdasarkan hasil validasi dari expert review, tim dosen dan uji one-to-one dapat dinyatakan bahwa bahan ajar dan lingkungan pembelajaran berbasis LSLC yang dikembangkan telah memenuhi kriteria valid.

Bahan ajar yang telah valid disebut dengan draft 2 bahan ajar. Hasil bahan ajar yang sudah valid kemudian diujicobakan melalui simulasi praktek mengajar di kelas oleh 12 orang 
subjek penelitian. Ujicoba difokuskan untuk melihat validitas dan reliabilitas dari bahan ajar pada lingkungan pembelajaran berbasis LSLC. Hasil ujicoba terbatas pada simulasi menunjukkan bahwa lingkungan pembelajaran berbasis LSLC dan bahan ajar sistem persamaan linier telah sesuai dengan kriteria kevalidan baik ditinjau dari sisi isi maupun dari segi kontsruk pengembangannya. Sehingga layak untuk digunakan pada kegiatan pembelajaran yang berorientasi meningkatkan kompetensi pedagogis calon guru matematika.

Pada penelitian ini kepraktisan diperoleh dari data hasil angket dan wawancara yang dilakukan setelah simulasi selesai. Berdasarkan analisis data angket dan wawancara diperoleh hasil bahwa lingkungan belajar berbasis LSLC dan bahan ajar yang dikembangkan sudah terkategori praktis.

Bahan ajar yang telah valid dan praktis kemudian diimplementasikan dalam kegiatan pembelajaran di sekolah. Hal ini dilakukan untuk menghasilkan lingkungan belajar berbasis LSLC dan bahan ajar final. Implementasi pembelajaran pada ujicoba luas dilakukan oleh 34 orang mahasiswa Program Studi Pendidikan Matematika FKIP Universitas Muhammadiyah Bengkulu. Implementasi dilakukan di SMP Negeri 11 dan SMP Negeri 18 Kota Bengkulu.

Sebelum ke sekolah mahasiswa diberikan pembekalan awal mengenai latar belakang lesson study, munculnya LSLC, dan prinsip-prinsip yang ada dalam suatu pembelajaran berbasis LSLC (adanya sharing dan jumping task). Kegiatan pembekalan diberikan oleh dua orang dosen yang mempunyai pengalaman melakukan kegiatan lesson study. Mahasiswa diberikan dua jenis lembar kerja siswa berkaitan dengan sharing dan jumping task.

Pada lembar kerja yang pertama ini mahasiswa diberikan lembar kerja berkaitan dengan sharing task. Hampir semua mahasiswa dapat mengerjakan lembar kerja tanpa bantuan orang lain. Selanjutnya mahasiswa diberikan lembar kerja kedua yang berisi jumping task. Lembar Kerja 2 tergolong pada jumping task, sehingga beberapa mahasiswa tidak dapat mengerjakan soal secara langsung. Awalnya mahasiswa bingung, namun etelah meminta bantuan teman dengan terlebih dahulu mengatakan 'tolong ajari saya' (membangun komunitas saling belajar), meminta penjelasan dan mendiskusikannya bersama. Setelah berdiskusi permasalahan di lembar kerja 2 dapat dikerjakan dengan baik.

Setelah pembekalan selesai, mahasiswa diberi angket yang berisi tentang pendapat atau pandangan mahasiswa terhadap kegiatan pembelajaran yang sudah dilaksanakan. Angket diberikan bertujuan untuk menilai apakah kegiatan pembelajaran yang dilakukan telah memenuhi kaedah atau prinsip yang terdapat pada LSLC. Indikator dalam kuesioner ini didasarkan pada prinsip sharing dan jumping task, saling belajar, dan tidak siswa yang 
terabaikan. Penjelasan hasil penghitungan angket materi pada simulasi dapat dilihat pada tabel 2 berikut.

Tabel 2. Hasil belajar angket

\begin{tabular}{lcc}
\hline \multicolumn{1}{c}{ Indikator } & N & Rerata \\
\hline Prinsip jumping task & 34 & 3,45 \\
Prinsip saling belajar & 34 & 3,28 \\
Prinsip tidak ada siswa yang & 34 & 3,01 \\
terabaikan & & \\
Rerata total & & 3,24 \\
\hline
\end{tabular}

Hasil angket pada tabel 2, memperlihatkan bahwa simulasi kegiatan pembelajaran yang dilakukan telah sesuai dengan prinsip-prinsip pembelajaran LSLC dengan rerata total rerata sebesar 3,24. Selain angket, juga dilakukan wawancara dan diskusi terkait simulasi pembelajaran agar mahasiswa lebih memahami tentang LSLC.

Langkah berikutnya adalah diskusi terkait perangkat pembelajaran berbasis LSLC dan mahasiswa diberi tugas untuk membuat perangkat pembelajaran berupa rencana pelaksanaan pembelajaran (RPP), lembar kerja dan diskusi siswa (LKPD), instrumen tes kemampuan berpikir tingkat tinggi (HOTs) dan petunjuk bagi guru. Mahasiswa bekerja secara berkelompok dan setiap kelompok mempunyai materi yang berbeda.

Subjek penelitian ini terdiri dari 34 orang mahasiswa yang terbagi dalam 8 kelompok, sehingga pada tahap perencanaan menghasilkan delapan (8) perangkat pembelajaran berbasis LSLC. Selanjutnya mahasiswa berlatih melaksanakan kegiatan pembelajaran dalam bentuk peer teaching. Setiap kelompok terdiri dari 4 atau 5 orang anggota, satu orang berperan sebagai seorang 'guru model', yang tiga atau empat orang lainnya sebagai observer. Mahasiswa dari kelompok lain berperan sebagai siswa. Setelah pembelajaran berakhir mahasiswa mendiskusikan hasil pengamatan dan pengalaman (lesson learnt) yang diperolehnya. Peserta diskusi memberikan pendapat terhadap bahan ajar yang ditampilkan oleh setiap kelompok. Pendapat dari kelompok lain menjadi masukan dalam untuk mendesain ulang yang bahan ajar (tahap mendesain ulang/redesign).

Setelah kegiatan peer teaching selesai dilaksanakan, mahasiswa mengimplementasikan hasil rancangannya di sekolah. Mahasiswa dan guru merencanakan proses pembelajaran secara bersama-sama, mengujicobakan lembar kerja siswa yang telah dirancang kepada beberapa siswa (one-to-one), merevisi, kemudian mengaplikasikannya dalam pembelajaran di kelas. Bahan ajar awal yang digunakan oleh guru model adalah yang bahan ajar yang telah dirancang oleh mahasiswa pada saat pembekalan di kampus. Diskusi antara mahasiswa 
dengan guru dilakukan untuk menyesuaikan bahan ajar yang telah dirancang dengan kondisi siswa. Selanjutnya bahan ajar tersebut divalidasi kepada beberapa orang siswa.

Kegiatan berikutnya adalah open class, yang dilakukan oleh mahasiswa bersama dengan guru. Pelaksanaan open class dilakukan di dua kelas yang berbeda pada setiap sekolah. Selama open class mahasiswa mengamati dan menganalisis pembelajaran yang sedang berlangsung (tahap do dan see). Kegiatan di sekolah diakhiri dengan melakukan refleksi.

Setelah melakukan implementasi di sekolah, mahasiswa diberi angket untuk mengetahui efek potensial lingkungan belajar berbasis LSLC terhadap kemampuan pedagogisnya. Data angket kepuasan terhadap lingkungan belajar yang diberikan oleh mahasiswa disajikan pada tabel 3 berikut.

Tabel 3. Hasil angket kepuasan lingkungan belajar

\begin{tabular}{llll}
\hline \multicolumn{1}{c}{ Indikator } & \multicolumn{1}{c}{ Pernyataan } & \multicolumn{1}{c}{ Rerata } & \multicolumn{1}{c}{ Sd } \\
\hline Pembelajaran berbasis LSLC & $1-7$ & 3,382 & 0,410 \\
Bahan ajar berbasis LSLC & $8-12$ & 3,195 & 0,299 \\
Perkuliahan & $13-15$ & 3,25 & 0,361 \\
\hline
\end{tabular}

Tabel 3 di atas memperlihatkan bahwa rerata mahasiswa menyetujui pernyataan bahwa lingkungan belajar yang diikuti (berpola lesson study) menarik, memberikan manfaat, dan suatu cara baru yang digunakan dalam pembelajaran. Demikian pula dengan bahan ajar yang digunakan seperti konteks dunia nyata, lembar kerja, tugas yang berupa sharing dan juga jumping task membuat siswa antusias untuk berpartisipasi dalam pembelajaran. Kemudian dilakukan triangulasi data angket yang diperoleh dengan melakukan interview terhadap mahasiswa. Hasil triangulasi menunjukkan bahwa semua mahasiswa memberikan pendapat bahwa kegiatan perkuliahan yang dilakukan telah memenuhi kriteria menarik dan sangat bermanfaat.

Berkaitan dengan kompetensi pedagogis mahasiswa dilakukan penilaian berdasarkan indikator (1) Menguasai karakteristik siswa, (2) Menguasai teori belajar dan prinsip-prinsip pembelajaran berbasis LSLC, (3) Melaksanakan kegiatan pembelajaran, (4) Memfasilitasi pengembangan potensi siswa, (5) Melaksanakan evaluasi proses dan hasil belajar, dan (6) Melakukan refleksi. Tabel 4. berikut menunjukkan kompetensi pedagogis mahasiswa.

Tabel 4. Kompetensi Pedagogis

Komponen Rerata Persentase

Menguasai karakteristik siswa

4,25

$85 \%$

Menguasai teori belajar dan prinsip-prinsip pembelajaran berbasis

LSLC

$4,5 \quad 90 \%$


Melaksanakan kegiatan pembelajaran

$\begin{array}{cc}5 & 100 \% \\ 4,25 & 85 \% \\ 5 & 100 \% \\ 5 & 100 \% \\ \text { Total } & 93,33 \%\end{array}$

Tabel 4 di atas memperlihatkan hasil penilaian terhadap kompetensi pedagogis mahasiswa setelah pembelajaran. Hasil penilaian menunjukkan bahwa kompetensi pedagogis mahasiswa setelah pembelajaran reratanya adalah 93,33\%. Hal ini menunjukkan bahwa kemampuan pedagogis mahasiswa sudah mengalami peningkatan, karena sebelum pembelajaran kompetensi pedagogis mahasiswa hanya sebesar $47,56 \%$.

\section{Pembahasan}

Berdasarkan hasil observasi, dalam menyusun bahan ajar mahasiswa masih mengalami kesulitan dalam memilih konteks yang tepat. Sedangkan dalam merancang bahan ajar, diperlukan penekanan pada pemilihan konteks yang tepat (Risdiyanti \& Indra Prahmana, 2020). Namun permasalahan tersebut dapat diatasi melalui komunitas saling belajar dan berdiskusi dalam kelompok. Pada akhirnya semua kelompok dapat menemukan konteks yang sesuai dengan bahan ajar yang dikembangkannya. Hal ini menunjukkan bahwa komunitas saling belajar merupakan lingkungan yang tepat bagi mahasiswa dalam menyusun bahan ajar yang baik. Mahasiswa bekerja dalam tim untuk membuat bahan ajar secara kolaboratif dan setiap langkah membantu mahasiswa untuk meningkatkan kemampuan pedagogis mereka. Hal ini menunjukkan bahwa adanya peningkatan kompetensi pedagogis mahasiswa (SalasRueda, 2019; Hernawati \& Jailani, 2019; Ozudogru \& Ozudogru, 2019).

Implementasi kegiatan di sekolah dilakukan secara kolaborasi antara mahasiswa dengan guru. Hal ini merupakan suatu lingkungan belajar yang sangat baik bagi mahasiswa dalam meningkatkan kemampuan pedagogisnya. Kolaborasi dilakukan dengan mengikuti tahapan dalam lesson study yaitu dimulai dari perencanaan pembelajaran (plan), melakukan pembelajaran dan mengamatinya (do), dan melakukan refleksi (see). Dalam pembelajaran yang berbasis lesson study for learning community, kolaborasi memainkan peranan penting bagi mahasiswa untuk memahami materi. Selain itu konteks yang digunakan juga memberikan pengaruh terhadap pemahaman siswa (Asari et al., 2018; Wessels, 2018; Landry, 2010).

Pada pelaksanaan kegiatan pembelajaran di kelas, kemampuan mahasiswa berada pada kategori baik. Mahasiswa dapat membuka pelajaran dengan sangat baik yang meliputi 
mempersiapkan dan memberikan motivasi kepada siswa, memberikan kaitan materi dan menyampaikan tujuan pembelajaran. Pada kegiatan inti, mahasiswa juga telah melakukannya dengan baik seperti mempunyai penguasaan materi, adanya kesesuaian pelaksanaan pembelajaran dengan prinsip dan karakteristik lesson study for learning community, bahasa yang digunakan sudah baik, mempunyai kepekaan sosial dan memiliki kepribadian sebagai guru yang baik.

Tingkat pemahaman mahasiswa terkait lesson study for learning community juga meningkat berdasarkan tes akhir yang diberikan. Mahasiswa diberi pertanyaan terkait pemahamannya mengenai prinsip dan karakteristik lesson study for learning community, hasilnya, 82,5\% mahasiswa mampu menjawab soal dengan baik. Terjadi peningkatan pemahaman yang cukup tinggi, karena pada awal penelitian hanya 11,7\% mahasiswa yang memahami lesson study for learning community. Selain itu kompetensi pedagogis mahasiswa juga meningkat setelah proses pembelajaran. Hal ini terlihat dari rerata kompetensi pedagogis mahasiswa setelah pembelajaran sebesar 93,33\%, sedangkan sebelum pembelajaran kompetensi pedagogisnya hanya sebesar $27,56 \%$.

Analisis data yang dilakukan memperlihatkan bahwa proses pengembangan lingkungan belajar yang dilakukan dapat meningkatkan kemampuan pedagogis mahasiswa calon guru matematika. Mahasiswa dapat mempersiapkan perangkat pembelajaran dan menerapkannya di kelas. Implementasi desain perangkat pembelajaran di lingkungan kampus dan sekolah juga menunjukkan hasil yang baik. Penggunaan lesson study for learning community sebagai sistem pembelajaran merupakan suatu sistem yang dapat membantu proses pengembangan lingkungan belajar yang lebih baik. Hal ini disebabkan prinsip lesson study yang menyatakan bahwa semua siswa mempunyai hak dan kewajiban yang sama dalam belajar. Sehingga tidak ada siswa yang terabaikan dalam pembelajaran di kelas (Sato, 2014).

\section{Simpulan}

Kompetensi pedagogis mahasiswa calon guru dapat ditingkatkan melalui pengembangan lingkungan belajar yang berbasis lesson study for learning community. Proses pengembangan dilakukan dengan model dari kampus ke sekolah, artinya pada tahap awal mahasiswa dilatih di lingkungan kampus yang dilanjutkan dengan latihan secara langsung di sekolah. Model ini terbukti dapat meningkatkan kompetensi pedagogis mahasiswa calon guru. Pelatihan terdiri dari penyampaian materi lesson study for learning community, simulasi pembelajaran melalui lesson study, diskusi dan pembuatan perangkat pembelajaran, peer teaching, penerapan pembelajaran berbasis lesson study for learning community di sekolah, 
diskusi akhir, dan tes. Lingkungan belajar berbasis lesson study for learning community yang dikembangkan telah memenuhi kriteria valid, praktis, dan mempunyai efek potensial untuk meningkatkan kemampuan pedagogis mahasiswa calon guru matematika.

\section{Referensi}

Asari, S., Fauziyah, N., \& Uchtiawati, S. (2018). Improving teacher pedagogic competences in remote areas through lesson study activity. International Journal of Education and Literacy Studies, 6(2), 53. https://doi.org/10.7575/aiac.ijels.v.6n.2p.53.

Brandt, J. O., Bürgener, L., Barth, M., \& Redman, A. (2019). Becoming a competent teacher in education for sustainable development: Learning outcomes and processes in teacher education. International Journal of Sustainability in Higher Education, 20(4), 630-653. https://doi.org/10.1108/IJSHE-10-2018-0183.

Caraka, P., \& Ika, M. (2016). Strategi LPTK dalam pengembangan kompetensi pedagogik calon guru. Jurnal Pendidikan (Teori Dan Praktik), 1(2), 96-106.

Dirgantoro, K. P. S. (2018). Kompetensi guru matematika dalam mengembangkan kompetensi matematis siswa. Scholaria: Jurnal Pendidikan dan Kebudayaan, 8(2), 157-166. https://doi.org/10.24246/j.js.2018.v8.i2.p157-166.

Guerrero, S. (2010). Technological pedagogical content knowledge in the mathematics classroom. Journal of Digital Learning in Teacher Education, 26(4), 132-139.

Hernawati, K., \& Jailani. (2019). Mathematics mobile learning with TPACK framework. Journal of Physics: Conference Series, 1321(2). https://doi.org/10.1088/17426596/1321/2/022126.

Kanellopoulou, E. M., \& Darra, M. (2019). The implementation of the lesson study in basic teacher education: A research review. Higher Education Studies, 9(3), 65. https://doi.org/10.5539/hes.v9n3p65.

Landry, G. A. (2010). Creating and validating an instrument to measure middle school mathematics teachers' technological pedagogical content knowledge (TPACK). Doctoral Dissertation, 1-93. http://trace.tennessee.edu/utk_graddiss/720.

Ozudogru, M., \& Ozudogru, F. (2019). Technological pedagogical content knowledge of mathematics teachers and the effect of demographic variables. Contemporary Educational Technology, 10(1), 1-24. https://doi.org/10.30935/cet.512515.

Perni, N. N. (2019). Kompetensi Pedagogik Sebagai Indikator Guru Profesional. Adi Widya: Jurnal Pendidikan Dasar, 4(2), 175. https://doi.org/10.25078/aw.v4i2.1122.

Rahman, B., Abdurrahman, A., Kadaryanto, B., \& Rusminto, N. E. (2015). Teacher-based scaffolding as a teacher professional development program in Indonesia. Australian Journal of Teacher Education, 40(11), 66-78. https://doi.org/10.14221/ajte.2015v40n11.4.

Rahman, M. H. (2014). Professional competence pedagogical competence and the performance of junior high school of science teachers. Journal of Education and Practice, 5(9), 75-80.

Risdiyanti, I., \& Indra Prahmana, R. C. (2020). The learning trajectory of number pattern learning using barathayudha war stories and uno stacko. Journal on Mathematics Education, 11(1), 157-166. https://doi.org/10.22342/jme.11.1.10225.157-166.

Risnanosanti, Susyla, D., \& Syofiana, M. (2019). Developing students critical thinking ability through lesson study. Journal of Physics: Conference Series, 1320(1). https://doi.org/10.1088/1742-6596/1320/1/012005.

Saito, E., \& Atencio, M. (2015). Lesson study for learning community (LSLC): conceptualising teachers' practices within a social justice perspective. Discourse, 36(6), 
795-807. https://doi.org/10.1080/01596306.2014.968095.

Salas-Rueda, R. A. (2019). TPACK: technological, pedagogical and content model necessary to improve the educational process on mathematics through a web application? International Electronic Journal of Mathematics Education, 1(1), 1-13. https://doi.org/10.29333/iejme/5887.

Sato, M. (2014). Dialogue and collaboration in the middle school: A community learning practice. Pelita-JICA.

Sukmawati, R. (2019). Analisis kesiapan mahasiswa menjadi calon guru profesional berdasarkan standar kompetensi pendidik. Jurnal Analisa, 5(1), 95-102. https://doi.org/10.15575/ja.v5i1.4789.

Susanto, R., Asmi Rozali, Y., \& Agustina, N. (2019). Development of pedagogical competency models for elementary school teachers: pedagogical knowledge, reflective ability, emotional intelligence and instructional communication pattern. Universal Journal of Educational Research, 7(10), 2124-2132. https://doi.org/10.13189/ujer.2019.071010.

Syahruddin, S., Ernawati, A., Ede, M. N., B Abdul Rahman, M. A., Johari Sihes, A., \& Daud, K. (2013). Teachers pedagogical competence in school-based management: Case study in a public secondary school. Journal of Education and Learning (EduLearn), 7(4), 213. https://doi.org/10.11591/edulearn.v7i4.195.

Wessels, H. (2018). Noticing in pre-service teacher education: research lessons as a context for reflection on learners' mathematical reasoning and sense-making bt - Invited Lectures from the 13th International Congress on Mathematical Education (G. Kaiser, H. Forgasz, M. Graven, A. Kuzniak, E. Simmt, \& B. Xu (eds.); pp. 731-748). Springer International Publishing. https://doi.org/10.1007/978-3-319-72170-5_41.

Widoyoko, E. P. (2013). Evaluasi program pembelajaran: panduan praktis bagi pendidik dan calon pendidik. Pustaka Pelajar.

Yuliyanti, Y., Winarso, W., \& Misri, M. A. (2019). Analisis profil guru matematika dalam membangun konsep diri siswa. Jurnal Mathematic Paedagogic, 3(2), 107. https://doi.org/10.36294/jmp.v3i2.417. 